\title{
Detection of Perkinsus marinus in the oyster Crassostrea rhizophorae in southern Bahia by proteomic analysis
}

\section{Detecção de Perkinsus marinus na ostra Crassostrea rhizophorae do sul da Bahia por análise proteômica}

\author{
Thiago Ramos PINTO ${ }^{1,2}$; Guisla BOEHS ${ }^{1,2}$; Wallace Felipe Blohem PESSOA ${ }^{3}$; Mariane dos Santos Aguiar \\ LUZ $^{1,2}$; Helena COSTA ${ }^{3}$ \\ ${ }^{1}$ Universidade Estadual de Santa Cruz, Programa de Pós-Graduação em Ciência Animal, Ilhéus - BA, Brazil \\ ${ }^{2}$ Universidade Estadual de Santa Cruz, Laboratório de Moluscos Marinhos, Ilhéus - BA, Brazil \\ ${ }^{3}$ Universidade Estadual de Santa Cruz, Laboratório de Proteômica do Centro de Biotecnologia e Genética, Ilhéus - BA, Brazil
}

\begin{abstract}
This study reports the presence of the pathogen Perkinsus marinus, notifiable to the World Organization for Animal Health (Office International des Ėpizooties = OIE) in the oyster Crassostrea rhizophorae in southern Bahia via proteomic analysis. We analyzed Crassostrea brasiliana from a long-line cultivation system and C. rhizophorae from an adjacent mangrove in Porto do Campo, Camamu Bay, Bahia, Brazil. The collections $(n=100)$ were performed in October 2012. In the laboratory, the oysters were measured and opened to remove the meat, which was steeped in dry ice. For extraction of proteins, adaptation of a protocol used for mussels was used, after which separation in the first dimension was taken by isoelectric focusing (IEF). The peptides were transferred to a Mass Spectrometer. The obtained spectra were analyzed with the ProteinLynx Global Server 4.2 software tool and also by MASCOT (Matrix Science) and compared to the databases of the SWISSPROT and NCBI, respectively. The identification was evidenced by beta-tubulin, Perkinsus marinus ATCC 50983 and protein homology code in the database NCBI = gi $\mid$ 294889481. This is the first record of P. marinus in Bahia and the fourth in Brazil.
\end{abstract}

Keywords: “Dermo”. Diseases. Oysters. Perkinsiosis.

\section{Resumo}

Este estudo relata a presença do patógeno Perkinsus marinus, de notificação obrigatória à Organização Internacional de Epizootias (OIE) na ostra Crassostrea rhizophorae no sul da Bahia, via análise proteômica. Foram analisadas as ostras Crassostrea brasiliana de um cultivo em espinhel e C. rhizophorae de um manguezal adjacente, na localidade de Porto do Campo, Baía de Camamu, Bahia. As coletas $(n=100)$ foram efetuadas em outubro de 2012. Em laboratório, as ostras foram medidas e abertas para a retirada da carne, que foi macerada em gelo seco. Para a extração das proteínas, foi adotada a adaptação de um protocolo utilizado para mexilhões, após o que foi realizada a separação na primeira dimensão, por focalização isoelétrica (IEF). Os peptídeos foram transferidos para um Espectrômetro de Massas. Os espectros obtidos foram analisados no software ProteinLynx Global Server $4.2 \mathrm{e}$ também pela ferramenta MASCOT (Matrix Science) e comparados com os bancos de dados do SWISSPROT e do NCBI, respectivamente. A identificação foi evidenciada por meio da beta-tubulina, homologia Perkinsus marinus ATCC 50983 e código da proteína no banco de dados NCBI = gi|294889481. Este é o primeiro registro de P. marinus na Bahia e o quarto no Brasil.

Palavras-chave: “Dermo”. Doenças. Ostras. Perkinsiose. 
Correspondence to:

Guisla Boehs

Universidade Estadual de Santa Cruz, Departamento de

Ciências Biológicas

Rodovia Jorge Amado, km 16

CEP 45662-900, Ilhéus, BA, Brazil

E-mail: gboehs@uesc.br

Received: 22/09/2015

Approved: 108/09/2016

Protozoa of the genus Perkinsus (Perkinsozoa) affecting bivalve mollusks in various regions of the world and can cause major economic losses depending on the species and the affected host. Among the six species currently considered valid, two ( $P$. marinus and $P$. olseni), due the severity of infection, they are notifiable to the World Organization for Animal Health (VILLALBA et al., 2004). The infection caused by these protozoa is known as Perkinsiosis or also as "Dermo", in reference to the first denomination of this protozoan made in the oyster C. virginica, in USA (MACKIN et al., 1950). The first record of Perkinsus in South America was made in Uruguay (CREMONTE et al., 2005), in the case of P. olseni, subsequently registered in the state of Sergipe, Brazil (SILVA et al., 2014). Perkinsus marinus has been registered in Brazil, in the states of Paraiba (SILVA et al., 2013), Sergipe (SILVA et al., 2014) and Ceará (DANTAS NETO, 2015). The species registered in the state of Bahia is P. beihaiensis (LUZ; BOEHS, 2016).

The oysters of the genus Crassostrea (Ostreidae) are important extractive resources around the Brazilian coast and its farming is already practiced in several places. On the coast of Bahia, the cultivation of these oysters is practiced on a small scale, mainly involving traditional extractive communities in the Bay of Iguape (Salvador) and in the municipalities of Valença, Taperoá, Camamu and Maraú, located further south. Monitoring of the diseases is already done in some of these crops (COVA et al., 2015; LUZ; BOEHS, 2015).

Oysters for this study were collected in October 2012, wherein C. brasiliana from a long-line cultivation system and C. rhizophorae in an adjacent mangrove, both located in Porto do Campo, Camamu Bay, Bahia, Brazil $\left(13^{\circ} 57^{\prime} \mathrm{S}, 39^{\circ} 02^{\prime} \mathrm{W}\right)$. The oysters were placed in buckets containing a small amount of seawater and transported to the State University of Santa Cruz (UESC), where they were immediately processed. The specimens were measured on the dorsal-ventral axis (= height), according Galtsoff (1964), then opened with a knife for removal of soft tissues (flesh) and sample preparation for extraction of proteins, which included maceration on dry ice. For this procedure, the protocol used by Diz and Skibinski (2007) for protein extraction of Mytilus edulis and M. galloprovincialis (Mytilidae) was adapted. After that, separation in the first dimension was taken by isoelectric focusing (IEF). Separated peptides were transferred to a Mass Spectrometer (Micromass QTOFmicro, Waters) and ionized in a capillary voltage of $3000 \mathrm{~V}$, fragmented in positive mode with selection of the minimum relative intensity of 10 counts. The obtained spectra were analyzed with the ProteinLynx Global Server 4.2 software (WATERS) as well by tool MASCOT (Matrix Science) and compared to the databases of the SWISSPROT and NCBI, respectively.

The identification of oysters was done by DNA sequencing. The results showed that the oysters farming were $C$. brasiliana and mangrove oysters were C. rhizophorae. The mean height of C. rhizophorae was $4.65 \pm 0.74 \mathrm{~cm}(\mathrm{n}=50)$ and of C. brasiliana was $5.43 \pm$ $0.47 \mathrm{~cm}(\mathrm{n}=50)$.

The pathogen, which was evidenced only in $C$. rhizophorae, could be identified through the presence of beta-tubulin, Perkinsus marinus ATCC 50983 homology with molecular weight of 50685 Daltons, Iso Electric Point $=4.73$, Score $($ score of protein $)=102$ and protein code in the database NCBI gi $=\mid 294889481$.

The primary objective of this study was to map the proteins of the oysters of the genus Crassostrea, as this knowledge is important both for the management of natural stocks as of oysters in cultivation. The laboratory tools typically used for detection of the 
genus Perkinsus in marine mollusks are: tissue analysis (histology), culturing in Ray's fluid thioglycollate medium (RFTM) and polymerase chain reaction (PCR). These three techniques allow the secure identification of this protozoan in the genus level, and perform the calculation of prevalence (= number of individuals infected/number of individuals collected). Histology and RFTM also enable the evaluation of the severity of the infection. According to previous studies (e.g., SILVA et al., 2014; LUZ; BOEHS, 2016), based on international protocol (OIE, 2009), to obtain the identification of the species, should do the following DNA sequencing of the PCR and perform phylogenetic analysis. Although all the above techniques are labor intensive, they are usually used together for monitoring this important pathogen worldwide. In a study conducted by Luz and Boehs (2016) in the same places, P. marinus was not detected by the techniques mentioned. The detection of $P$. marinus through proteomics proved to be in this case

\section{References}

COVA, A. W.; SERAFIM JÚNIOR., M.; BOEHS, G.; SOUZA, J. M. Parasites in the mangrove oyster Crassostrea rhizophorae cultivated in the estuary of the Graciosa River in Taperoá, Bahia. Revista Brasileira de Parasitologia Veterinária, v. 24, n. 1, p. 21-27, 2015. doi: 10.1590/S198429612015012.

CREMONTE, F.; BALSEIRO, P.; FIGUERAS, A. Occurrence of Perkinsus olseni (Protozoa: Apicomplexa) and other parasites in the venerid commercial clam Pitar rostrata from Uruguay, southwestern Atlantic coast. Diseases of Aquatic Organisms, v. 64, n. 1, p. 85-90, 2005. doi: $10.3354 /$ dao064085.

DANTAS NETO, M. P. Patógenos na ostra Crassostrea rhizophorae de estuários da costa setentrional do Nordeste brasileiro. 2015. 115 f. Tese (Doutorado em Ciências Marinhas Tropicais) - Instituto de Ciências do Mar, Universidade Federal do Ceará, Fortaleza, 2015.

DIZ, A. P.; SKIBINSKI, D. O. F. Evolution of 2-DE protein patterns in a mussel hybrid zone. Proteomics, v. 7, n. 12, p. 2111-2120, 2007. doi: 10.1002/pmic.200600954. more sensitive than molecular tools conventionally used, indicating that perhaps this pathogen is present in low prevalence and/ or low number in the tissues in the study region. The detection probably was only possible because pools of oysters were used in the proteomic analysis, which probably promoted a concentration of the beta-tubulin, Perkinsus marinus ATCC 50983. Then, proteomics can be used as an additional tool in the detection of this pathogen.

This is the first record of P. marinus in Bahia and the fourth in Brazil, all in northeastern Brazil.

\section{Acknowledgements}

Funding agencies FAPESB, for project financing (TSC0010 / 2011) and CAPES, for granting master's scholarship to the first author. Prof. Carlos Priminho Pirovani for the grant of use of the Proteomics Laboratory at the Center for Biotechnology and Genetics (CBG/UESC) for analysis.

GALTSOFF, P. S. The American oyster, Crassostrea virginica (Gmelin). Washington, D.C.: Fishery Bulletin of the Fish and Wildlife Service, 1964. 480 p.

LUZ, M. S. A.; BOEHS, G. Parasites in the oyster Crassostrea rhizophorae from farmed and natural stocks in the Bay of Camamu, Bahia, northeastern Brazil. Journal of Parasitology and Vector Biology, v. 7, n. 6, p. 120-128, 2015. doi: 10.5897/JPVB2015.0198.

LUZ, M. S. A.; BOEHS, G. Perkinsus beihaiensis infecting the oyster Crassostrea rhizophorae under cultivation and in natural stock in Camamu Bay, Bahia, Brazil. Brazilian Journal of Veterinary Research and Animal Science, v. 53, n. 2, p. 191-198, 2016. doi: 10.11606/issn.16784456.v53i2p191-198.

MACKIN, J. G.; OWEN, H. M.; COLLIER, A. Preliminary note on the occurrence of a new protistan parasite, Dermocystidium marinum n. sp., in Crassostrea virginica 
(Gmelin). Science, v. 111, n. 2883, p. 328-329, 1950. doi: 10.1126/science.111.2883.328.

WORLD ORGANISATION FOR ANIMAL HEALTH (OIE). Manual of diagnostic tests for aquatic animals $6^{\text {th }}$ ed. Paris: OIE, 2009. 383 p.

SILVA, P. M.; SCARDUA, M. P.; VIANNA, R. T.; MENDONÇA, R. C.; VIEIRA, C. B.; DUNGAN, C. F.; SCOTT, G. P.; REECE, K. S. Two Perkinsus spp. infect Crassostrea gasar oysters from cultured and wild populations of the Rio São Francisco estuary, Sergipe, northeastern Brazil. Journal of Invertebrate Pathology, v. 119, p. 62-71, 2014. doi: 10.1016/j.jip.2014.04.005.
SILVA, P. M.; VIANNA, R. T.; GUERTLER, C.; FERREIRA, L. P.; SANTANA, L. N.; FERNÁNDEZ-BOO, S.; RAMILO, A.; CAO, A.; VILLALBA, A. First report of the protozoan parasite Perkinsus marinus in South America, infecting mangrove oysters Crassostrea rhizophorae from the Paraíba River (NE, Brazil). Journal of Invertebrate Pathology, v. 113, n. 1, p. 96-103, 2013. doi: 10.1016/j.jip.2013.02.002.

VILLALBA, A.; REECE, K. S.; ORDÁS, M. C.; CASAS, S. M.; FIGUERAS, A. Perkinsiosis in molluscs: a review. Aquatic Living Resources, v. 17, n. 4, p. 411-432, 2004. doi: 10.1051/alr:2004050. 